\title{
THE COST OF TRANSITION FROM MARKET TO COMMAND \\ 1 ECONOMY: THE CASE OF ESTONIA
}

\section{Olaf Mertelsmann}

Tartu University, E-mail: omertelsmann@yahoo.co.uk

An earlier version of this paper has been presented at the XIVth International Economic History Congress in Helsinki 2006

\begin{abstract}
:
While the post-socialist transition of central and eastern European economies has produced a large amount of research, the transition to the command economy has been explored mainly in the cases of Russia and East Germany. This paper is an updated summary of the results of a larger research project which is dedicated to the Stalinist reconstruction of Estonia's economy and the postwar years. It is based mainly on archival research in Estonian and Russian archives using documents of the state and the Communist Party.
\end{abstract}

\section{Rezumat:}

Studiile ştiintifice au abordat adesea subiectul tranzitiei economice postsocialiste în cazul tărilor central şi est-europene. Rareori a fost tratată însă tema tranzitiiei de la economia de piață la economia de comandă, după intrarea acestor țări în sfera de interes a Uniunii Sovietice. Studiile care există în acest domeniu se concentrează mai ales asupra cazului Rusiei sau al Germaniei de Est. Acest articol îmbogăteşte tocmai această arie de cercetare, tratând subiectul tranzitiei de la economia de piață la economia de comandă în cazul Estoniei, fenomen care s-a produs în perioada 19401941, respectiv 1944-1955. Lucrarea se constituie în mare măsură din concluziile aduse la zi ale unui vast proiect de cercetare dedicat reconstruirii staliniste a Estoniei în anii postbelici. Sursele de documentare au fost constituite în principal de documente din arhivele de stat şi partid estoniene şi ruseşti, precum şi de statisticile sovietice. Acest studiu arată că trecere la economia de comandă a produs o serie întreagă de efecte negative asupra economiei estoniene, atât pe termen scurt, cât şi pe termen 
lung. Pe termen scurt a întârziat recuperarea tării de pe urma războiului şi a produs scăderea nivelului de trai, crescând considerabil rata mortalitătiii. Pe termen lung a împiedicat dezvoltarea economică ulterioară a Estoniei, care după război a fost depăşită de multe tări care în perioada interbelică se aflaseră în urma sa din punct de vedere economic (Spania, Grecia, Portugalia). Abia după recâştigarea independentei în 1991, Estonia a putut continua recuperarea întârzierilor, după o a doua tranzitie post-stalinistă, recupareare care încă nu s-a încheiat. Este dificil de estimat când anume Estonia va atinge media dezvoltării economice din UE. Cert este însă că dacă Estonia este astăzi din punct de vedere economic sub această media, faptul este într-o mare măsură datorat economiei de comandă din perioada sovietică.

Keywords: Estonia; transition; market economy; command economy

While the post-socialist transition of central and eastern European economies has produced a large amount of research, the transition to the command economy has been explored mainly in the cases of Russia and East Germany. ${ }^{1}$ The Republic of Estonia which was occupied and annexed by the Soviet Union in 1940 and occupied by Nazi Germany 1941-44 provides us with the opportunity of a case study of one former independent state transferred into a Soviet republic. This paper is an updated summary of the results of a larger research project which is dedicated to the Stalinist reconstruction of Estonia's economy and the postwar years. ${ }^{2}$ It is based mainly on archival research in Estonian and Russian archives using documents of the state and the Communist Party. Of course, Soviet economic statistics bear a lot of methodological

\footnotetext{
${ }^{1}$ For example E.H. Carr and R.W. Davies, Foundations of a Planned Economy, 1926-1929, vol. 1 (London: Macmillan, 1969); R.W. Davies, ed., From Tsarism to the New Economic Policy: Continuity and Change in the Economy of the USSR(London and Basingstoke: Macmillan, 1990); R.W. Davies, Mark Harrison and S.G. Wheatcroft, eds., The Economic Transformation of the Soviet Union, 1913-1945 (Cambridge, Cambridge University Press, 1994); Wolfgang Zank, Wirtschaft und Arbeit in Ostdeutschland 1945-1949. Probleme des Wiederaufbaus in der Sowjetischen Besatzungszone Deutschlands (Munich:R.Oldenbourg, 1987); Dierk Hoffmann, Aufbau und Krise der Planwirtschaft. Die Arbeitskräftelenkung in der SBZ/DDR 1945 bis 1963 (Munich: Oldenbourg Wissenschaftsverlag, 2002); André Steiner, Von Plan zu Plan: Eine Wirtschaftsgeschichte der DDR(Munich: Deutsche. VerlagsAnstalt, 2004).

2 Olaf Mertelsmann, Der stalinistische Umbau in Estland: Von der Markt-zur Kommandowirtschaft (Hamburg: Kovac, J, 2006).
} 
problems. ${ }^{3}$ Because of this, the original sources are quoted or well-founded estimations used. 4

For several decades the Socialist countries claimed to possess a planned economy, but recent research on the mechanisms of Soviet economic policy supports the argument to characterise the economic system as a command economy. ${ }^{5}$ Comparatively few areas were really 'planned', fixed prices, resource allocation, personal networks and direct interference from higher standing authorities played a major role in economic policy.

In Estonia, the transition from the market to the command economy happened gradually and was more or less finished after the forced collectivisation of agriculture, the largest sector of the Estonian economy, in the first half of the 1950s. Since the beginning of the process of the dissolution of the Soviet Union at the end of the 1980s, there was an ongoing discussion on the benefits the incorporated Baltic States may have received from becoming part of the USSR. Especially industrialisation, investment, and economic growth were stressed as positive results, because in the interwar period Estonia, Latvia, and Lithuania were mainly agrarian. This paper tries to address some of the costs of the transition process and asks whether a country like Estonia did in fact benefit from being part of the Soviet Union. From today's perspective, obviously economic backwardness and a low level of per capita GDP seems to be directly related with the experience of nearly half a century of command economy. Stalinist terror, the war damages ${ }^{6}{ }^{6}$ and the German occupation influenced economic performance negatively, too. This means, not all costs and losses might by ascribed to economic transition only. Still, measures like a mass deportation in 1949 with roughly 20,000 victims to prepare the country for

\footnotetext{
3 See S.G. Wheatcroft and R. W. Davies, 'The Crooked Mirror of Soviet Economic Statistics', eds. Davies, Harrison, Wheatcroft, 1994, 24-37.

${ }^{4}$ For a broader discussion, see Mertelsmann, 2006. A recent publication provides us with some solid data series based on official statistics: Martin Klesment and Jaak Valge, eds., Eesti rahvastiku majandustegevuse näitarve XX sajandil / Estonian 20th Century Economic Indicators (Tallinn:EKDK, 2007).

5 Paul R. Gregory, ed., Behind the Façade of Stalin's Command Economy (Stanford: Hoover Institution Press, 2001); Paul R. Gregory, The Political Economy of Stalinism: Evidence from the Soviet Secret Archives (Cambridge: Cambridge University Press, 2004); Andrei Markevich, 'Byla li sovetskaia ekonomika planovoi? Praktika planirovaniia v narkomatakh v 1930-gg', Ekonomicheskaia istoriia. Ezhegodnik 2003, 20-54; Andrei Markevich, 'Soviet Planning Archives: the Files that Bergson could not see', Comparative Economic Studies 47 (2005): 364-86.

${ }^{6}$ Archival research revealed that the war damages were in fact substantially smaller than officially claimed by the Soviets. Mertelsmann, 2006, 88-93.
} 
collectivisation had also an economic agenda and cannot be seen only under the category of terror and cleansing. ${ }^{7}$

Statistical data for independent Estonia offers with 1938 a good year of comparison, because Estonian GDP has been recalculated up to this time and a first economic census has been conducted in this very year. ${ }^{8}$ In the post-war period the year 1955 is another good point of comparison, because post-war reconstruction was finished officially and a number of important statistics use 1955 as a benchmark year.

\section{The human costs}

The first period of economic transition 1940-41 followed basically a timeframe developed in Eastern Poland from 1939 onwards after the region was occupied and annexed as Western Ukraine and Western Belarus by the USSR. This is revealed from the Zhdanov files in the former Party Archives in Moscow. Andrei Zhdanov served during the communist takeover in Estonia as Stalin's plenipotentiary in the country to coordinate Sovietisation. On the 21 July 1940 he received a nine pages telegram from Moscow, which outlined the economic restructuring in Western Ukraine from summer 1939 until spring 1940.9 The content of this telegram served obviously as a blueprint for the economic reforms to take place in the Baltic republics, some measures were implemented exactly one year later then in Eastern Poland.

Enterprises employing 20 or more and all banks were nationalised, bank accounts frozen, stocks and bonds confiscated. Owners of larger houses were expropriated and a maximum norm for living space per capita was introduced. The Soviets closed the borders and international trade diminished. A first land reform reduced larger farms to a maximum size of 30 hectares. Fixed prices were introduced as was state procurement at fixed, too low prices in agriculture. Apart from agriculture, roughly only one tenth of enterprises remained privately owned. With the communist take-over, inflation started and did not stop after the introduction of a new currency - the rouble. During one year, inflation was at least twice as high

\footnotetext{
7 Rein Taagepera, 'Soviet Collectivization of Estonian Agriculture: The Deportation Phase', Soviet Studies XXXII (1980): 379-97.

8 Jaak Valge, 'Uue majanduse lätteil. Eest sisemajanduse kogutoodang aastatel 1923-1938' [On the Border of a New Economic Level: Estonian GDP 1923-1938], Akadeemia 15 (2003): 2202-28, 2443-86, 2712-35; Riigi Statistika Keskbüroo, I majandusloendus Eestis [The first economic census in Estonia], 4 vols. (Tallinn: Riigi trükikoda, 1939-1940).

9 Telegram to Zhdanov, 21 July 1940, Rossiiskii gosudarstvennyi arkhiv sotsial'nopoliticheskoi istorii (Russian State Archive of Socio-Political History, RGASPI) f. 77, o. 4, d. 40, 1. 62-70.
} 
as the increase in nominal salaries. Reports on the sentiment of the population stressed that a fast decline of the standard of living was the major topic of complaining. ${ }^{10}$ Obviously, the economy was shrinking as a result of transition. In addition, the Soviets conducted a policy of plundering local resources. Exports to the 'old republics' of the USSR at low prices outnumbered several times imports at high prices from there. Estonia had also to take the burden to feed and to house the units of the occupying Red Army constituting of roughly 100,000 soldiers or the equivalent of nearly one tenth of the Estonian population. ${ }^{11}$

According to the famous calculation of Soviet national income by Abram Bergson less than half of the Soviet national income of that time was used for private consumption. ${ }^{12}$ In independent Estonia private consumption consisted of approximately 75-80 percent of national income. In other words, even if the economy did not shrink, consumption was severely constrained. As a result, the standard of living fell dramatically and the crude death rate increased rapidly. This fact might be seen as a clear indicator of an economic catastrophe 1940-41. The usual crude death rate in the 1930s was between 14 and 15 cases per thousand inhabitants per year. ${ }^{13}$ The increase was so dramatic that it outnumbered the average level of the period from 1901-1914.14 In December 1940 the death rate peaked at 27.7, nearly twice the usual level. Mainly small children and the old aged composed the additional deaths. ${ }^{15}$ From January to April 1941, the rate averaged at 20.0.16 Of course, there are seasonal changes in the death rate, but such a dramatic development indicates clearly a drastic decline in nutritional standards. In a country like Estonia which was a natural food exporter with originally 0.8 hectares of land under culture and a total of 2.7 hectares agricultural land per inhabitant, food scarcity could have occurred, if the distributional system was collapsing and large amounts of food were exported to the Soviet Union or consumed by the Red Army.

\footnotetext{
${ }^{10}$ Local reports on the sentiment of the Estonian population 1940-41, Eesti Riigiarhiivi Filiaal (Branch of the Estonian State Archives, ERAF) 1-1-45 - 1-1-59.

11 See chapter 1 in Mertelsmann, 2006, 29-74.

12 Abram Bergson, The Real National Income of Soviet Russia since 1928 (Cambridge MA: Harvard Univerity Press, 1961), 277.

13 See Odile Frank and Marta Gacic Dobo, 'Historical Records, Mortality Decline and Changing Causes of Death: Estonia and Uruguay in the Twentieth Century', World Health Statistics Quarterly 51 (1998): 145-173.

14 Arnold Veimer, Kompleksnoe razvitie i specializatsiia promyshlennosti Estonskogo Ekonomicheskogo Administrativnogo Raiona (Tallinn, 1961), 77.

15 Statistical information concerning the death rate in December 1940, Eesti Riigiarhiiv (Estonian State Archives, ERA) R-10-1-486, 1. 1-4.

16 Analysis of mortality in the first four months of 1941, ERAF 1-1-187, 1. 3.
} 
One has to bear in mind that in 1940 per capita roughly $350 \mathrm{~kg}$ of rye, wheat and barley, more than one ton of potatoes, 700 litres of milk and more than $50 \mathrm{~kg}$ of meat were produced in Estonia. ${ }^{17}$

As a result of transition, the middle and upper classes lost property. Many former entrepreneurs or managers were arrested, deported or even killed later. Often members of their families were deported, too, or at least discriminated for decades because of their social background. For the vast majority of the population transition meant a rapid decline of the standard of living. If we are searching for answers to the question, why the German invaders were greeted as liberators in the summer of 1941, in the opinion of the author there were three main reasons: 1) Stalinist terror; 2) the loss of independence; and 3) the desperate economic situation as a result of the first year of transition.

In 1944, the Red Army re-occupied Estonia. War damages, casualties and a mass flight to the West had changed Estonia and her population. Population losses of a country with originally only 1.13 million inhabitants were enormous (see table 1) and could be compensated only by inmigration of Russian speakers and return migration of ethnic Estonians. Approximately 200,000 Russians settled down in Estonia until 1959,18 the year of the first Soviet population census in the country. With the beginning of collectivization in 1949, the size of rural population started to decline. At first because of a mass deportation, later the main reason was the unbearable situation on the kolkhozes. Urbanisation grew rapidly, but this should not be seen as the result of a 'natural' process or modernisation. For immigrants it was easier to settle down in towns and collectivised agriculture was not attractive. The peasants referred to it as a 'second serfdom' and tried to leave the countryside.

Tab. 1: Population of Estonian 1945-55 in Thousand

\begin{tabular}{|l|l|l|l|l|l|l|}
\hline Year & Urban & Rural & Total & Urban & Rural & Total \\
\hline 1945 & 267 & 587 & 854 & & & \\
\hline 1946 & 305.7 & 575.3 & 881 & & & \\
\hline 1947 & 363.4 & 593.7 & 957 & & & \\
\hline 1948 & 415.9 & 607 & 1,022 & & & \\
\hline 1949 & 439.9 & 589.2 & 1,029 & & & \\
\hline 1950 & 487 & 593.7 & 1,080 & 516.1 & 580.6 & $1,096.7$ \\
\hline 1951 & 519.1 & 568.8 & $1,087.9$ & 548.4 & 555.6 & 1,104 \\
\hline 1952 & 550.1 & 563.5 & $1,113.6$ & 579.5 & 542.2 & $1,129.8$ \\
\hline
\end{tabular}

17 Calculation based on Klesment, Valge, eds.,2007, 62, 66, 68.

18 Mertelsmann, 2006, 129. 


\begin{tabular}{|l|l|l|l|l|l|l|}
\hline 1953 & 569.6 & 555.5 & $1,125.1$ & 599.1 & 528.2 & $1,141.3$ \\
\hline 1954 & 592.8 & 541.4 & $1,134.2$ & 622 & 528.2 & $1,150.2$ \\
\hline 1955 & 605.2 & 536.9 & $1,142.2$ & 634.1 & 523.2 & $1,157.3$ \\
\hline
\end{tabular}

Without military personnel.

Columns $4-6$ corrected after the census in 1959.

Source: ERA R-10-43-155, 1. 1-3.

At least a part of the population losses were also a direct result of the transition to command economy and the exploitation policy of the Nazi occupiers. For three years, the birth rate was below the death rate and the recorded death rate for at least six years above normal levels (see table 2). As earlier mentioned, hunger should usually not occur in an agricultural surplus country like Estonia, because there was an abundance of land and food production would be sufficient to feed the entire population. Of course the war and infectious diseases were responsible for part of the increase in the death rate. The given table should only be seen as indicating the tendency in development, because especially the death rate was in the opinion of the author not calculated correctly. From other sources we might get slightly different data. Victims of state terror were excluded, the data on the German period seems not to be accurate and there might have been some manipulations concerning infant mortality. The decline of the death rate in the 1950s was not so much caused by increasing nutritional standards, but by a certain improvement in medical care which took place all over the Soviet Union in the post-war period. The high birth rate after the war appears to be related to two factors, a catching-up effect and a higher number of births among immigrants, who were mainly in a fertile age. According to the known statistics, approximately 40,000 additional deaths might be ascribed to low nutritional standards in the 1940s. This was nearly the size of the number of the victims of Stalinist terror, clearly outnumbered the war casualties and exceeded the amount of Estonians killed by the Nazis five times. ${ }^{19}$

Tab. 3: Registered Births and Deaths per Thousand Inhabitants, 1938-56

\begin{tabular}{|c|l|l|c|}
\hline Year & Births & Deaths & Natural Growth \\
\hline 1938 & 16.3 & 14.6 & +1.7 \\
\hline 1939 & 16.3 & 15.1 & +1.2 \\
\hline 1940 & 16.4 & 17.0 & -0.6 \\
\hline
\end{tabular}

\footnotetext{
${ }^{19}$ See Aigi Rahi-Tamm, 'Deportation und Verfolgung in Estland 1940-1953', ed., Olaf Mertelsmann, Vom Hitler-Stalin-Pakt bis zu Stalins Tod. Estland 1939-1953 (Hamburg, 2005), 212-3.
} 


\begin{tabular}{|l|l|l|l|}
\hline $1941-4$ & 16.1 & 15.0 & +1.1 \\
\hline 1945 & 17.3 & 23.9 & -6.6 \\
\hline 1946 & 21.1 & 21.7 & -0.6 \\
\hline 1947 & 22.9 & 21.7 & +1.2 \\
\hline 1948 & 21.2 & 17.1 & +4.1 \\
\hline 1949 & 21.4 & 16.4 & +5.0 \\
\hline 1950 & 18.7 & 14.6 & +3.9 \\
\hline 1951 & 18.8 & 13.9 & +4.9 \\
\hline 1952 & 18.9 & 14.1 & +4.8 \\
\hline 1953 & 17.8 & 12.8 & +5.0 \\
\hline 1954 & 18.4 & 12.3 & +6.1 \\
\hline 1955 & 18.2 & 11.9 & +6.3 \\
\hline 1956 & 17.1 & 11.1 & +6.0 \\
\hline
\end{tabular}

Without victims of terror or war.

Column 4 calculated based on 2 and 3 .

Source: ERA R-10-43-155, 1. 6.

During the entire 1940s, the population faced severe cuts in their nutritional standards and real incomes, but we do not have precise budget data. In the 1950s, the situation improved in the towns, while it worsened in the countryside thanks to collectivisation. Based on state prices, it has been estimated that average incomes had lost at least half of the purchasing power in 1955 compared to the late 1930s, ${ }^{20}$ but this estimation could not regard the availability of goods in an 'economy of shortages'. Real incomes are hard to estimate for a country, where not the nominal money incomes but the accessibility of food, goods and services determined the standard of living. Because of this, budget data on food consumption provides somehow better information about living standards. In 1938, a large survey of households of industrial workers and state employees was conducted (see table 3). The peasant diet was not researched, but seemed to be quite similar to the situation of workers. The diet appears to be diverse and sufficient, while state officials were able to consume more quality food. Compared to other European countries, Estonians were obviously better fed than the majority of South and Eastern Europeans, and the Germans or the Irish. They were nearly reaching the food standards of Western European countries. Human development factors like infant mortality

${ }^{20}$ Aleksander Kaelas, Das sowjetisch besetzte Estland (Stockholm, 1958), pp. 101-2. 
indicate a similar relation. ${ }^{21}$ The share of food in Estonian household expenditure was 40 percent in 1937.22

Tab. 3: Food Consumption of Families of Workers and State Employees in 1938 per Capita in Kilos

\begin{tabular}{|l|c|c|c|c|}
\hline & $\begin{array}{l}\text { Worker } \\
\text { per year }\end{array}$ & $\begin{array}{l}\text { Worker per } \\
\text { months }\end{array}$ & $\begin{array}{l}\text { State employee } \\
\text { per year }\end{array}$ & $\begin{array}{l}\text { State } \\
\text { employee } \\
\text { per month }\end{array}$ \\
\hline Vegetables & 59.4 & 5.0 & 64.5 & 5.4 \\
\hline Fruits & 38.4 & 3.2 & 53.2 & 4.4 \\
\hline Bread & 175.7 & 14.6 & 178.9 & 14.9 \\
\hline Potatoes & 159.2 & 13.3 & 180.7 & 15.1 \\
\hline Fish & 27.5 & 2.3 & 37.0 & 3.1 \\
\hline Meat & 63.3 & 5.3 & 61.5 & 5.1 \\
\hline Milk & 227 & 18.9 & 253 & 21 \\
\hline Sugar & 29.8 & 2.5 & 35.8 & 3.0 \\
\hline
\end{tabular}

Source: Riigi Statistika Keskbüroo: I majandusloendus Eestis: Büdžetiuurimus [The first economic census in Estonia. Budget survey], vol. IV (Tallinn, 1940), pp. 83-6.

Having a closer look on the relation between incomes per capita and food consumption reveals that there was an important difference in food intake in 1938 (see table 4). Lower wages meant less food, but at least the average seems to be somehow sufficient. Of course, in independent Estonia there existed poverty especially among unskilled workers, smallholders and farmhands with larger families.

Tab. 4: Per Capita Food Consumption of Workers' Households in 1938

\begin{tabular}{|c|c|c|c|}
\hline $\begin{array}{l}\text { Per capita income } \\
\text { in Estonian crowns }\end{array}$ & $\begin{array}{l}\text { Daily calorie } \\
\text { intake }\end{array}$ & Protein & Fat \\
\hline 25 and less & 2,935 & 86 & 74 \\
\hline $26-35$ & 3,189 & 95 & 82 \\
\hline $36-45$ & 3,305 & 101 & 92 \\
\hline $46-55$ & 3,527 & 105 & 102 \\
\hline $56-65$ & 3,705 & 115 & 109 \\
\hline
\end{tabular}

\footnotetext{
21 See Statistisches Jahrbuch für das Deutsche Reich 1938 (Berlin, 1938), pp. 382-5, 307*-310*. 22 Timo Toivonen, 'Classes, Countries and Consumption Between the World Wars: A Comparison of the Structure of Expenditure in Estonia, Finland and Sweden in the 1920s and 1930s', Acta Sociologica 35 (1992): 224-5.
} 


\begin{tabular}{|l|c|c|c|}
\hline 66 and more & 3,405 & 112 & 120 \\
\hline Average & 3,405 & 102 & 94 \\
\hline
\end{tabular}

Source: Riigi Statistika Keskbüroo, I majandusloendus Eestis: Büdžetiuurimus, p. 78.

Comparing the data from 1938 with surveys from the early 1950s demonstrates that real incomes and food provision did not fully recover from the decline in the 1940s. This was a result of the policy of constraining consumption for the sake of investment and military expenses in the early Cold War. ${ }^{23}$ Food consumption of workers was far below of the standards of the pre-war period (see table 5). They did not go hungry in the early 1950s, but a certain lack of fats, proteins and vitamins might be seen clearly. More than before the war, the diet was based on bread and potatoes. In addition, there were current complaints on the quality of food provided by the state owned retail shops. For example, Estonians referred to Soviet bread of that time as 'pig's cake'. The average calorie intake per capita in Estonia was still the highest among all Soviet republics in 1954 according to Soviet statisticians. ${ }^{24}$

Tab. 5: Food Consumption of Estonian Worker's Households, per Months and Capita in Kilo, 1952-56

\begin{tabular}{|c|c|c|c|c|c|c|c|c|c|}
\hline & $\begin{array}{l}\frac{\pi}{2} \\
\text { ही }\end{array}$ & 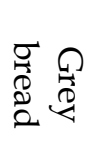 & 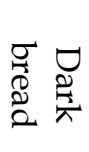 & 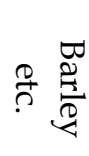 & 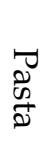 & $\begin{array}{l}0 \\
0 \\
0 \\
0 \\
0 \\
0 \\
0 \\
0\end{array}$ & 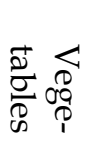 & 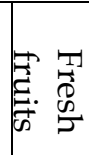 & 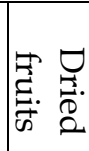 \\
\hline 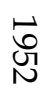 & $\begin{array}{l}\text { P } \\
\infty \\
\infty\end{array}$ & 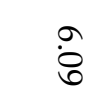 & $\stackrel{0}{\circ}$ & i & $\stackrel{\circ}{\circ}$ & $\underset{i \sim}{\vec{\Delta}}$ & $\stackrel{\omega}{\sim}$ & $\stackrel{\circ}{v}$ & $\stackrel{\circ}{\circ}$ \\
\hline 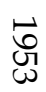 & $\ddot{\omega}$ & $\stackrel{u}{v}$ & $\begin{array}{l}\infty \\
\infty\end{array}$ & i & : & $\vec{N}$ & $\stackrel{\vec{c}}{\vec{r}}$ & $\dot{\sim}$ & $\stackrel{\circ}{\circ}$ \\
\hline $\begin{array}{l}\vec{b} \\
\text { o }\end{array}$ & $\vec{\omega}$ & $\tilde{\sigma}$ & iv & $\stackrel{\circ}{\circ}$ & 으 & $\underset{\infty}{\vec{\infty}}$ & $\stackrel{\vec{N}}{\mathbf{N}}$ & $\overrightarrow{6}$ & $\stackrel{\circ}{\circ}$ \\
\hline $\begin{array}{l}\text { : } \\
\text { : }\end{array}$ & $\ddot{i}$ & $\stackrel{\sim}{N}$ & $\ddot{a}$ & $\ddot{0}$ & : & $\stackrel{\sim}{\sim}$ & $\stackrel{p}{\dot{c}}$ & $\vec{\sigma}$ & $\stackrel{\circ}{\circ}$ \\
\hline
\end{tabular}

${ }^{23}$ A certain share of investment was in fact used for the military, but it did appear in the statistics as civil investment. For example the investment plan for the first half year of 1946 was only fulfilled by two thirds, 23 percent of the money was needed for military installations. Statistical overview, RGASPI f. 598, o. 1, d. 9, 1. 117.

24 Elena Zubkova et al., eds., Sovetskaia Zhizn 1945-1953 (Moscow, 2003), 129. 


\begin{tabular}{|c|c|c|c|c|c|c|c|c|c|}
\hline ঢ़ & $\dot{\vec{N}}$ & $\stackrel{N}{N}$ & $\stackrel{\infty}{\sigma}$ & $\dot{0}$ & 우 & $\stackrel{N}{0}$ & cr & $\overrightarrow{6}$ & $\stackrel{\circ}{\rightarrow}$ \\
\hline & $\begin{array}{l}\text { E: } \\
\text { 㤩 } \\
\infty\end{array}$ & 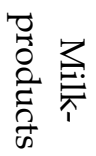 & 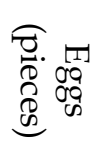 & 勇 & 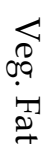 & $\begin{array}{l}3 \\
\stackrel{3}{0} \\
\stackrel{2}{*}\end{array}$ & 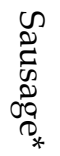 & : & 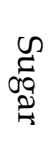 \\
\hline 灾 & $\underset{\text { i }}{\vec{N}}$ & $\stackrel{\circ}{i \omega}$ & 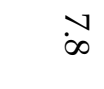 & $\stackrel{\ominus}{\ominus}$ & ¿ & $\stackrel{N}{N}$ & : & $\stackrel{\varphi}{\omega}$ & $\ddot{i s}$ \\
\hline 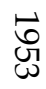 & 후 & $\stackrel{\circ}{i}$ & $\stackrel{0}{\dot{N}}$ & $\stackrel{\circ}{\circ}$ & $\stackrel{\circ}{\text { if }}$ & $\stackrel{N}{\stackrel{N}{*}}$ & ? & $\stackrel{\vec{i}}{\vec{i}}$ & $\overrightarrow{6}$ \\
\hline & $\stackrel{\bullet}{0}$ & $\stackrel{\circ}{i}$ & $\begin{array}{l}\overrightarrow{0} \\
\text { à }\end{array}$ & : & $\stackrel{\circ}{\text { if }}$ & $\stackrel{N}{G}$ & $\dot{\vec{r}}$ & is & No \\
\hline$\vec{\jmath}$ & $\underset{\omega}{\vec{\omega}}$ & $\stackrel{\circ}{i}$ & 6 & $\stackrel{\vec{r}}{\vec{r}}$ & $\stackrel{\circ}{\text { if }}$ & $\begin{array}{l}N \\
G\end{array}$ & $\stackrel{\vec{r}}{\overrightarrow{2}}$ & $\stackrel{\vec{i}}{\vec{b}}$ & $\overrightarrow{0}$ \\
\hline $\begin{array}{l}\text { ठ্ } \\
\text { जू }\end{array}$ & $\underset{\infty}{\vec{N}}$ & 우 & 6 & $\stackrel{\vec{\nu}}{ }$ & $\stackrel{\circ}{i \infty}$ & $\stackrel{N}{\alpha}$ & $\overrightarrow{\mathrm{N}}$ & $\stackrel{\vec{i}}{ }$ & $\stackrel{\bullet}{v}$ \\
\hline
\end{tabular}

* Soviet sausage at that time did usually not contain much meat.

Source: Budget survey 1952-56, ERA R-10-43-57, 1. 19-20.

The sources of food, except for bread, reveal that the majority was privately produced (see table 6). The prices on the kolkhoz market were substantially exceeding the ones of state retail trade. The Soviet state was unable to feed the workers and was forced to allow all sort of private economic activities to avoid starvation. Thus, private garden plots in the towns and in the countryside provided for the majority of food. Survival strategies were needed and included all sort of illegal activities from stealing state property to the black market or moonshining. ${ }^{25}$

Tab. 6: Sources of Food for Estonian Workers 1952-6

\begin{tabular}{|c|l|c|c|c|c|c|c|c|c|}
\hline Year & \multicolumn{3}{|c|}{ Potatoes in kg } & \multicolumn{3}{c|}{ Vegetables } & \multicolumn{3}{c|}{ Fresh fruits } \\
\cline { 2 - 10 } & $\begin{array}{l}\text { State } \\
\text { trade }\end{array}$ & Market & $\begin{array}{l}\text { Private } \\
\text { hands }\end{array}$ & $\begin{array}{l}\text { State } \\
\text { trade }\end{array}$ & Market & $\begin{array}{l}\text { Private } \\
\text { hands }\end{array}$ & $\begin{array}{l}\text { State } \\
\text { trade }\end{array}$ & Market & $\begin{array}{l}\text { Private } \\
\text { hands }\end{array}$ \\
\hline 1952 & 0.5 & 8.9 & 7.9 & 0.5 & 2.1 & 0.5 & 0.1 & 0.5 & 0.1 \\
\hline
\end{tabular}

25 Olaf Mertelsmann, 'Estonian Moonshine in the 1940s', Humanitāro Zinātñu Vēstnesis 3 (2004), No. 6: 86-95; Olaf Mertelsmann, 'Mehrdimensionale Arbeitswelten als Überlebensstrategie während der stalinistischen Industrialisierung am Beispiel Estlands', Burghart Schmidt, Jürgen Hogeforster, eds., Mehrdimensionale Arbeitswelten im baltischen Raum (Hamburg: Studien zum Ostseeraum, 2007), 94-106. 


\begin{tabular}{|l|l|l|l|l|l|l|l|l|l|}
\hline 1953 & 0.3 & 7.1 & 9.2 & 1.0 & 2.7 & 1.4 & 0.1 & 1.0 & 02 \\
\hline 1954 & 0.2 & 6.7 & 12.3 & 1.1 & 2.4 & 0.6 & 0.2 & 1.4 & 0.3 \\
\hline 1955 & 0.5 & 5.7 & 10.4 & 1.3 & 2.0 & 0.7 & 0.3 & 1.1 & 0.4 \\
\hline 1956 & 0.7 & 6.2 & 16.6 & 1.6 & 1.8 & 0.6 & 0.4 & 1.1 & 0.6 \\
\hline \multicolumn{9}{|c|}{ Milk litres } & \multicolumn{6}{|c|}{ Eggs (pieces) } & \multicolumn{3}{c|}{ Meat } \\
\hline 1952 & 1.3 & 7.5 & 2.2 & 0.5 & 6.5 & 0.2 & 0.1 & 2.0 & 0.3 \\
\hline 1953 & 1.2 & 6.8 & 3.5 & 0.5 & 7.4 & 0.3 & 0.2 & 1.5 & 0.3 \\
\hline 1954 & 1.2 & 7.4 & 4.0 & 1.0 & 7.7 & 0.7 & 0.3 & 1.5 & 0.6 \\
\hline 1955 & 1.5 & 7.8 & 3.6 & 1.8 & 5.6 & 1.2 & 0.6 & 1.0 & 0.4 \\
\hline 1956 & 3.6 & 6.7 & 3.5 & 3.6 & 4.6 & 0.8 & 1.1 & 0.8 & 0.4 \\
\hline
\end{tabular}

Source: Budget survey 1952-56, ERA R-10-43-57, 1. 25-6.

The situation of the food producers, the collectivized peasants, was even worse (see table 7). Because of collectivisation, peasants did not only loose their property and personal freedom being now tied to the kolkhoz, but also their standard of living declined. As a result, incentives to work on the kolkhoz in an efficient manner were barely existent. Several kolkhozes were so poor that collective work was not even paid at all.

Tab. 7: Peasant Food Consumption in 1952 per Capita and Month in Kilo

\begin{tabular}{|l|c|}
\hline Bread and flour & 11.0 \\
\hline Barley etc. & 1.6 \\
\hline Potatoes* & 18.1 \\
\hline Vegetables & 1.6 \\
\hline Fruits & 0.1 \\
\hline Animal Fat & 0.4 \\
\hline Meat & 3.4 \\
\hline Fish & 0.7 \\
\hline Milk & 13.1 \\
\hline Eggs (pieces) & 8.0 \\
\hline Sugar & 0.4 \\
\hline
\end{tabular}

* Partly fed to animals.

Source: Budget survey 1952, ERAF 1-114-57, 1. 38.

Vassilii Popov estimates that the share of food in the household expenditure of workers and employee in the USSR in 1950 was 79 percent. ${ }^{26}$ It seems safe to argue that this share should have been at least 70 percent in the early 1950s in the Estonian case. The Estonian population was forced to

\footnotetext{
26 Vassilii P. Popov, Ekonomicheskaia politika sovetskogo gosudarstvo 1946-1953 gg., (Moscow-Tambov, 2000), 65.
} 
sacrifice potential incomes in the name of Socialist reconstruction, industrialisation, and the Cold War. While Western Europe could recover much earlier from the war during the first half of the 1950s partly due to American support, it took longer in many parts of Eastern Europe. Obviously the transition to the command economy played a key role in the delay in the Estonian case. One might ask whether scarifying incomes for investment did pay off in the perspective of long-term economic growth.

In addition to lower real incomes and the temporary increase of the death rate, there were other human costs caused by the transition. Traditional rural life was destroyed by the collectivisation. Because the Stalinist state did not bother to construct sufficient housing for a rapidly growing urban population, urban living space per capita declined from 15.5 square meters in 1940 to 8.8 in 1955.27 The population in general was impoverished; the largest material losses were inflicted to members of the former middle and upper classes, but for the poor - especially the elderly and large families - transition could pose an existential threat. While we know a lot about the scale of political persecution, an unknown number of people - obviously more than 20,000 - was sent to the work camps or to prison because of 'crimes' conducted as a result of poverty and economic transition: peasants, who could not pay the high taxes imposed on them or did not fulfil their norms of 'forced' labour in wood cutting and road maintenance; 'speculators' and black market traders; people, who stole because of hunger; or victims of the draconian labour laws. In Stalin's Soviet Union after the war, the number of those 'criminals' exceeded the number of political prisoners several times. ${ }^{28}$

\section{Economic performance of the different sectors}

Since Socialist economies operated with so-called unchanged fixed prices and official growth statistics seem not to be very reliable, it is quite difficult to throw a glimpse on their performance. For the Soviet Union exist different estimates which indicate general trends. In the case of Estonian agriculture one might use data on physical production of certain products to understand the general development. For industry, statistics on gross production at fixed prices are available. Concerning the service sector, employment offers some help. It is quite clear that such kind of data

\footnotetext{
27 Romuald Misiunas and Rein Taagepera, The Baltic States: Years of Dependence 1940-1990 (London: Hurst \& Co, second edition, 1993), 364.

28 For the period 1946-1952, Donald Filtzer offers a figure of 495,000 convictions for political crimes and 4.8 million criminal offenders for the entire USSR. Roughly 34,000 Estonians were arrested during Stalinism for political reasons. Following the figures of Filtzer, approximately 25,000 Estonians might have been convicted for criminal offences.
} 
might form only the base for a rough estimation, while we have much more information concerning independent Estonia. According to the calculations of Jaak Valge, the distribution of employment and the GDP in different sectors in 1938 shows that the country was still mainly agrarian (see table 8 ). The highest per capita GDP was reached in industry and services, the lowest in agriculture, but differences were not huge.

Tab. 8: Distribution of Employment and GDP in Estonia in 1938

\begin{tabular}{|c|c|c|c|c|c|c|}
\hline \multicolumn{2}{|c|}{ Agriculture } & \multicolumn{2}{|c|}{ Industry } & \multicolumn{2}{|c|}{ Services } & \multirow{2}{*}{$\begin{array}{l}\text { Total } \\
\text { in } \\
\text { million } \\
\text { crowns }\end{array}$} \\
\hline $\begin{array}{l}\text { Million } \\
\text { crowns }\end{array}$ & $\begin{array}{l}\text { Employment } \\
\text { in percent }\end{array}$ & $\begin{array}{l}\text { Million } \\
\text { crowns }\end{array}$ & $\begin{array}{l}\text { Employment } \\
\text { in percent }\end{array}$ & $\begin{array}{l}\text { Million } \\
\text { crowns }\end{array}$ & $\begin{array}{l}\text { Employment } \\
\text { in percent }\end{array}$ & \\
\hline 50.1 & 55.8 & 130.3 & 19.8 & 154.9 & 24.4 & 535.3 \\
\hline
\end{tabular}

Source: Valge, Uue majanduse lätteil, pp. 2451, 2718.

When regarding the development of agriculture until the 1950s, one has to divide it into two different periods: before and after collectivisation. Up to 1949 , agriculture was privately owned and run except for state farms (sovkhozes). A second land reform after the first one in 1940 was finished in 1947. Peasants had to deliver part of the production at fixed prices to the state, had to pay increasing agricultural taxes often in kind and were able to consume or market the rest. Since 140,000 farms were hard to control there was room to evade at least partly from state procurement and taxation. In independent Estonia, agricultural prices were mainly related to the world market price. Under Soviet rule, a price system with several layers evolved for agricultural products: fixed state procurement prices, sales to state institutions or enterprises at higher prices, and market or black market prices. Since wholesale trade was in control of the state, private marketing faced enormous difficulties like the lack of transport or the threat being called a 'speculator'. This increased transaction cost and reduced the amount of marketable products. In addition, because of the scarcity of consumer goods peasants could not buy much for the money they earned on the market. Thus incentives for agricultural production declined. In addition, isolating the country from the outside world meant that new machinery, tools, spare parts, fodder and fertiliser could only be purchased at a reduced scale - if at all. There is evidence that peasant ceased to invest in their capital stock since 1940 because of their unclear future perspective. ${ }^{29}$ Lack of labour force thanks to population losses

\footnotetext{
29 This was noted for example by the contemporary eye-witness Paul Hinnov in a manuscript from 1960 which could be published only nearly 40 years later. Paul Hinnov, Kui need talud tapeti [When those Farms were killed], (Tartu, 1999), 13-4.
} 
hampered production, too. Collectivisation reduced private agriculture to small garden plots of the size of roughly 0.5 hectares per kolkhoz family. The state was able to purchase more agricultural output at fixed prices which were below production costs. Thanks to low or non-existent incomes there were few incentives to work on the kolkhoz and garden plots became basically the only location of intensified agricultural production. ${ }^{30}$ The Soviet calculation of the national income of the Estonian SSR for 1955 put the net value of private agricultural production as being twice as high as the net output of kolkhozes and sovkhozes together. ${ }^{31}$ The main purpose of collectivisation was channelling incomes from agriculture into other sectors, referred to as 'primitive socialist accumulation'. ${ }^{32}$

Since meat and milk production were crucial for Estonian agriculture, the number of farm animals is a first indicator of the development (see table 9). Compared to 1939, there was a substantial decline and military action in the summer of 1941 and in fall 1944 left also a trace. Obviously, the animal population could not recover to the pre-war level thanks to the circumstances of the command economy. But the number of farm animals is still overstating potential animal production, because for example weight at slaughter or milk production per cow is also important and did decline substantially. Official time series of meat production seem not to be plausible at all given the decline of the number of farm animals and the availability of fodder. ${ }^{33}$ In addition, in many kolkhozes farm animals starved to death each spring during the 1950s.

Tab. 9: Farm Animals in Estonia in Thousands 1939-1956

\begin{tabular}{|l|c|c|c|c|}
\hline & Cattle (total) & Cows & Pigs & Sheep and goats \\
\hline 1.7 .1939 & 675.4 & 458.9 & 425.9 & 657.9 \\
\hline 1940 & 597 & 419 & 371 & 488 \\
\hline 1.1 .1941 & 504.8 & 382.4 & 290.4 & 316.1 \\
\hline 1943 & 460 & No data & 274 & 258 \\
\hline End of 1944 & 336 & 193 & 169 & 206 \\
\hline 1945 & 401 & 226 & 196 & 264 \\
\hline 1946 & 410 & 234 & 201 & 250 \\
\hline 1947 & 436 & 248 & 237 & 264 \\
\hline 1948 & 445 & 259 & 232 & 268 \\
\hline
\end{tabular}

\footnotetext{
30 See chapter 5 in Mertelsmann, 2006, 167-202; On the collectivisation see also David Feest, Zwangskollektivierung im Baltikum: Die Sowjetisierung des estnischen Dorfes 1944-1953 (Cologne-Weimar-Vienna, 2007).

31 ERA R-10-19-1, 1. 8.

32 See Robert C. Allen, Farm to Factory: A Reinterpretation of the Soviet Industrial Revolution (Princeton: Princeton University Press, 2003), 57-8;_Gregory, 2004, 30-1. 33 For the official data see Klesment, Valge, eds., 2007, 68.
} 


\begin{tabular}{|l|l|l|l|l|}
\hline 1949 & 437 & 279 & 269 & 272 \\
\hline 1950 & 450 & 294 & 279 & 287 \\
\hline 1951 & 462 & 283 & 297 & 274 \\
\hline 1952 & 484 & 275 & 313 & 279 \\
\hline 1953 & 488 & 269 & 300 & 254 \\
\hline 1954 & 448 & 258 & 308 & 242 \\
\hline 1955 & 447 & 267 & 313 & 253 \\
\hline 1956 & 435 & 263 & 276 & 241 \\
\hline
\end{tabular}

Sources: 1939 and 1941, ERAF 1-47-49, 1. 61; 1940, 1943 and 1944, ERA R-6-16-1, 1. 8, 14; ERA R-10-43-133, 1. 1-22.

The following tables offers a glimpse on the situation of milk production which declined due to a lack of fodder (see tables 10 and 11). A first decline happened in the 1940s, a second one after collectivisation. The same might be said for the weight at slaughter. Because of manipulation of statistics the official total output data is not helpful for measuring animal production, since it was heavily overstated in the opinion of the author. When estimating with the help of available information, milk production declined from 1940 to 1955 by more than a half, meat production fell by more than 40 percent.

Tab. 10: Milk per Cow 1940/41 - 1947/48

\begin{tabular}{|l|l|c|}
\hline Year & Milk per cow in kilo & $\begin{array}{c}\text { Number of controlled } \\
\text { cows }\end{array}$ \\
\hline $1940 / 41$ & 2,924 & 62,823 \\
\hline $1944 / 45$ & 2,350 & 15,147 \\
\hline $1945 / 46$ & 2,257 & 16,906 \\
\hline $1946 / 47$ & 2,187 & 18,744 \\
\hline $1947 / 48$ & 2,311 & 21,416 \\
\hline
\end{tabular}

Source: ERAF 1-47-49, 1. 69.

Tab: 11: Milk per Cow in the kolkhoz 'Ühisjõud'

\begin{tabular}{|r|r|}
\hline 1950 & 2,214 \\
\hline 1951 & 1,654 \\
\hline 1952 & 1,906 \\
\hline 1953 & 1,668 \\
\hline 1954 & 1,299 \\
\hline
\end{tabular}

Source: Rahva Hääl [The People's Voice], 19 March 1955.

Crop production faced a similar development. The structure of the use of land changed in favour of lower income crops (see table 12). Meanwhile, the size of land under culture declined as well from approximately 900,000 
hectares in 1940 to roughly 700,000 hectares after the war. ${ }^{34}$ Concerning the size of land under culture, there were huge manipulations in official statistics, but data from the Statistical Office seems to be the most reliable which indicates such a decline. In addition, this developments seems logical in regards to diminishing incentives, workforce and draft power.

Tab. 12: Structure of Land under Culture 1940-1955 in Percent

\begin{tabular}{|c|c|c|c|}
\hline & 1940 & 1950 & 1955 \\
\hline Fodder & 25.6 & 28.8 & 40.5 \\
\hline Grain & 61.2 & 55.7 & 45.0 \\
\hline $\begin{array}{c}\text { Potatoes and } \\
\text { vegetables }\end{array}$ & 9.3 & 12.9 & 13.0 \\
\hline Technical cultures & 3.9 & 2.6 & 1.5 \\
\hline
\end{tabular}

Source: E. Vint, 'Põllumajanduse areng Nõukogude Eestis', Nõukogude Eesti majandus 1940-1960 (Tallinn, 1960), p. 79.

Even official data series demonstrate a tremendous fall in grain production (see table 13). Of course, the weather influenced grain output as did the lack of fertiliser, draft power or workforce. Still, the major reasons seem to be less effort by the peasants after collectivisation and the reduction of the size of the sown area. In this series the drop of the size of land under culture was not included, thus, total grain output seemed to be in fact one fifth smaller.

Tab. 13: Official Grain Harvest Data and estimated Net Harvest 1940 and 1945-56

\begin{tabular}{|l|c|c|c|}
\hline & $\begin{array}{c}\text { Grain harvest in } \\
\text { thousand tons (gross) }\end{array}$ & $\begin{array}{c}\text { Grain harvest in } \\
\text { thousand tons (net) }\end{array}$ & $\begin{array}{c}\text { Per hectare in } \\
\text { tsentner }\end{array}$ \\
\hline 1940 & 654 & 540 & 11.5 \\
\hline 1945 & 370 & 287 & 8.9 \\
\hline 1946 & 412 & 309 & 9.6 \\
\hline 1947 & 613 & 505 & 11.9 \\
\hline 1948 & 528 & 433 & 9,8 \\
\hline 1949 & 560 & 469 & 11.9 \\
\hline 1950 & 522 & 432 & 11.5 \\
\hline 1951 & 451 & 359 & 10.1 \\
\hline 1952 & 329 & 239 & 7.2 \\
\hline 1953 & 276 & 191 & 6.1 \\
\hline
\end{tabular}

\footnotetext{
34 See Statistical overview, ERA R-10-43-124, 1. 3; Karotamm to Malenkov, 26. October 1949, ERAF 1-14-113, 1. 71-2; Documents for the protocol of the meeting of the Central Committee Bureau of the Estonian Communist Party, 28. September 1950, ERAF 1-4-1045, 1. 17
} 


\begin{tabular}{|l|l|l|l|}
\hline 1954 & 281 & 211 & 6.6 \\
\hline 1955 & 228 & 161 & 6.7 \\
\hline 1956 & 288 & 222 & 8.7 \\
\hline
\end{tabular}

Column 3 calculated: net $=$ gross less seed needed for the next year. Source: ERA R-10-43-129, 1. 3, 77-8.

To sum it up, agricultural output declined substantially as a result of the transition. This situation was already known to contemporary researchers, ${ }^{35}$ but the newly available sources allow the conclusion that the fall in production was even larger than expected. This result does not astonish, since collectivisation in the Soviet Union led to a man-made famine, a kind of catastrophe Estonia was spared of. In the Soviet case, Stalinist industrialisation has been stressed at least as one 'positive' result of the command economy. So maybe the agricultural decline was compensated by industrial growth. Official data of industrial gross production (this is total output at fixed prices) might suggest a kind of fast transformation from an agrarian into an industrial society (see table 14).

Tab. 14: Official Index of Industrial Gross Production, 1940-55

\begin{tabular}{|l|l|}
\hline Year & Estonia \\
\hline 1940 & 1.0 \\
\hline 1945 & 0.73 \\
\hline 1950 & 3.42 \\
\hline 1955 & 6.7 \\
\hline
\end{tabular}

Source: Misiunas, Taagepera, The Baltic States, p. 361.

At the first glance the increase of production by 6.7 times seems to be a miracle and the index needs explanation. Actually, Soviet fixed prices were introduced in industry only step by step. In case of the base year 1940, accounting was originally done in Estonian crowns at prices of 1939 and simply converted at the official Soviet exchange rate of 1.25 roubles per crown into Soviet fixed prices. ${ }^{36}$ Since a realistic conversion into plan prices would be 6 roubles for 1 crown, the index starts with an extreme underestimation of the base year. ${ }^{37}$ In addition, there were certain index problems and hidden price inflation was included in Soviet production

\footnotetext{
35 See Arnold Purre, Soviet Farming Failure hits Estonia (Stockholm, 1964).

36 Meeting in the ESSR People's Commissariat of Light Industry, January 1941, ERA R-12-131, 1. 58.

${ }^{37}$ For the discussion Olaf Mertelsmann, 'Was there a Stalinist Industrialization in the Baltic Republics? Estonia - an Example', Olaf Mertelsmann, ed., The Sovietization of the Baltic States, 1940-1956 (Tartu, 2003), 151-170.
} 
data. ${ }^{38}$ Since the major target for Soviet managers was to fulfil the output plan in roubles, they had incentives to shift to more lucrative products, offering a higher fixed price which required less efforts and real inputs. Because of the fact that at the beginning of the base year the variety of products was determined by market conditions, Estonian managers had room to shift production during time. For example, the furniture producer 'Rahvamööbel' could increase output per worker at fixed prices by 7.6 times and the metal factory 'Metallmärk' by 5.4 times during the period of 1940-47, applying obviously this technique. ${ }^{39}$

More doubts concerning 'industrial growth' occur when regarding different factors. In the post-war period the infrastructure in Estonia was not improved sufficiently compared to the pre-war times. ${ }^{40}$ According to official data, industrial employment increased until 1955 to roughly $125,000.41$ But this is not a rise in comparison to the 19.8 percent of employment in the secondary sector in 1938 offered by Jaak Valge. ${ }^{42}$ Soviet industrial employment included a large amount of employees and by melting small enterprises and artisans into trusts, people, who have been not counted as industrial workers in the 1930s, became included. The industrial workforce was like their managers not well prepared and inexperienced. ${ }^{43}$ Mark Harrison has argued that the productivity per Soviet worker did not increase substantially during the period of 1928 to 1950.44 The decline of the standard of living in Estonia was a factor which could not improve the motivation of workers. In fact, turnover rates and absenteeism reached a peak in 1947, when in Republican enterprises 12 percent of the workers were absent and three thirds of the workers changed the place of employment. ${ }^{45}$ In other words, it is highly doubtful that the composition, motivation, and size of the workforce were responsible for industrial growth. In addition, investment and new technology were not provided to a sufficient extent to recover from the war damages and the

\footnotetext{
38 See Mark Harrison, 'Soviet Industrial Production, 1928 to 1955: Real Growth and Hidden Inflation', Journal of Contemporary Economics 28 (2000): 134-155.

${ }^{39}$ For more examples see statistical overview, ERAF 1-47-38, 1. 28-31.

40 Centralnoe Statisticheskoe Upravlenie ESSR, Estonskaia SSR za gody sovetskoi vlasti

(Tallinn, 1967), 105.

41 Statistical overview, ERA R-1-5-406, 1. 5.

42 Valge 2003, 2451.

43 Raimo Pullat, ed., Istoriia rabochego klassa Sovetskoi Estonii (Tallinn, 1985), 338, 345;

Veimer, Kompleksnoe razvitie, 317.

44 Mark Harrison, 'Wartime mobilization: a German comparison', John Barber and Mark Harrison (eds.), The Soviet Defence-Industry Complex from Stalin to Khrushchev (LondonNew York, 2000: Macmallin Press), 110.

45 Statistical overview, ERA R-12-3-27, 1. 11-3; report by Gosplan of the ESSR, 4 December 1948, ERAF 1-7-27, 1. 33.
} 
losses of capital stock until the second half of the 1950s.46 As mentioned above, part of industrial investment was in reality consumed by the military, a certain amount of large projects were finished only years later and misallocation of capital into the wrong industries did take place substantially.

It is difficult to estimate when industrial output reached again the prewar level, but in the opinion of the author it is even possible that it happened only at the end of the 1950s. The rapid industrial growth officially announced did obviously not happen. The reduction of consumption did not lead to expected results, because the investment did not create fast growth. The command economy was unable to provide the institutional setting for a sustainable development in the post-war period in Estonia. In addition, the Soviet Union favoured heavy industry over light industry producing consumer goods.

Because Soviet fixed prices did not mirror sufficiently production costs, the scarcity of resources and demand, the probability of wrong resource allocation grew the longer the command economy existed. In fact, it was not even always possible to decide whether an industrial plant was a constant loss maker or was profitable. ${ }^{47}$ In post-war Estonia for example, the oil shale industry was given high priority and absorbed 40 percent of entire investment. ${ }^{48}$ Under market conditions in the inter-war period, oil shale mining and processing received subsidies and were protected by tariffs, ${ }^{49}$ it might be doubtful whether this industry was ever profitable in the given period, but the Soviets even increased the scale. Apart from making the wrong economic decision and burdening the country up to today with industrial dinosaurs, the use of oil shale inflicted enormous environmental damages. ${ }^{50}$ The enormous expansion of the oil shale industry, which triggered immigration into the mining region, might clearly be seen as a negative result of transition.

If agriculture did suffer from transition and industry did not recover quickly, maybe the service sector could benefit? Indeed, a large expansion

\footnotetext{
46 See Mertelsmann 2003

47 See Clifford G. Gaddy and Barry W. Ickes: Russia's Virtual Economy (Washington D.C.: The World Bank, 2002), 47-9.

48 Kalev Kukk, 'Industry', Juhan Kahk (ed.), World War II and Soviet Occupation in Estonia: A Damages Report (Tallinn, 1991), 64.

49 Jaak Valge, 'Riiklik põlevkivitööstuse majandustingimused ja -tulemused 1920. ja 1930. aastatel', Akadeemia 7 (1995), 1712-1740, 1929-1949.

50 The use of oil shale as a source of energy is only profitable, when energy prices are high like in recent years. In regards of the natural resources of the Soviet Union, the exploitation of Estonian oil shale made economically only sense in the immediate post-war situation, when many coal fields could not be operated due to war damages.
} 
of services happened, because of an increase in the provision of public goods like medical care, education, science or culture. In addition, operating a non-market economy created the need for a large bureaucracy, and employment in defence or security in the USSR was highly above a normal level. Since in the system of fixed prices, services were due to ideological reasons to a large extent undervalued, estimations of the importance of the service sector have to take the employment structure into consideration (see table 15).

Tab. 15: Distribution of Estonian Workforce according to the Plan 1955 in Thousands

\begin{tabular}{|l|l|}
\hline Total (“Labour reserve“) & 702.1 \\
\hline a.) Employment in state or cooperative institutions & 356.3 \\
\hline Of this in: Industry & 122.6 \\
\hline Building & 22.2 \\
\hline Transport and communication & 44.9 \\
\hline Sovkhozes and forestry & 50.2 \\
\hline Trade & 25.2 \\
\hline Education & 25.2 \\
\hline Health & 19.0 \\
\hline b.) Cooperatives of craftsmen & 13.5 \\
\hline c.) Kolkhozes & 154.4 \\
\hline d.) Learning. 16 and older & 38.0 \\
\hline e.) Independent farmers and craftsmen & 0.9 \\
\hline $\begin{array}{l}\text { f.) Working age population employed at home or in private } \\
\text { economy (“domashnie ili lichnoe khozaistvo")* }\end{array}$ & 139.0 \\
\hline
\end{tabular}

* Mainly garden plots, but also petty trade and other forms of minor employment.

Without military and security.

Source: ERA R-1-5-406, 1. 5-6.

Based on table 15 and including the Estonian share in the armed forces, one might estimate the size of employment in the single sectors. The primary sector should include the majority of those persons being "employed at home or in private economy", too, because they were taking care of the garden plots and private farm animals. A minority of the last category belonged to the service sector working for example as selfemployed petty traders. Thus approximately one fifth of the workforce was employed in industry and two fifth in agriculture and roughly the same amount in services. One has to add that a large share of the non-agrarian population was generating additional incomes on private garden plots which might have been for a certain time even more important than their 
salaries. This was for example the case of the majority of teachers in the countryside. Nearly the total rural population and approximately half of the urban households possessed some kind of garden plots.

Compared to 1938 when one fourth of the workforce had been employed in services, the share of service employment rose substantially. This implies that the sector should have faced some real growth which could not be said about agriculture and industry. While per capita GDP in industry and services seemed to be quite similar before the war (see table 8 above), the situation in 1955 was obviously different. According to wage statistics, incomes in services fell far below the level of industry in the 1950s. ${ }^{51}$ While higher ranking administrators were well paid, the mass of bureaucrats received low salaries. Medicine, culture, or education lost substantially ground. Compared to the pre-war period, educational levels of physicians, teachers or scientists had declined, while their number increased. Many people faced marginal employment in services. Because of the inefficient institutions, more persons were needed to adjust the deficits of the command economy. For example the volume of retail trade was much smaller, because of lower real incomes, still more people were employed in the state trade sector or worked as petty traders to sell less goods than before the war. This increased transaction costs and the number of persons receiving marginal incomes. It might be argued that like in other sectors productivity per capita declined in the service sector. ${ }^{52}$

According to a Soviet calculation of the national income of the Estonian SSR, net production reached 4.6 billion roubles (see table 16). Usually in Soviet publications gross production was used which measured total output without reducing this figure by costs or inputs of each sector. Thus, net production seems to be a better indicator. Because the fixed prices reflect the preferences of the planers, industrial output was overrated, agriculture and the service sector undervalued. A direct comparison with the pre-war GDP at market prices in crowns seems nearly impossible. In the opinion of the author, on the average one Estonian crown should be the equivalent of approximately 10-12 roubles at current plan prices of 1955 .

\footnotetext{
51 Veimer, Kompleksnoe razvitie, 328.

52 See chapter 7 in Mertelsmann, 2006, 241-56.
} 
Tab. 16: Official Estimation of Gross and Net Production per Sector at Current Plan Prices in Million Roubles and of the Distribution of Workforce in 1955

\begin{tabular}{|l|c|c|c|}
\hline Sector & $\begin{array}{c}\text { Gross } \\
\text { Production }\end{array}$ & $\begin{array}{c}\text { Net } \\
\text { Production }\end{array}$ & $\begin{array}{c}\text { Estimated Distribution } \\
\text { of Workforce in Percent }\end{array}$ \\
\hline Agriculture & 2,675 & 1,473 & 41 \\
\hline Industry & 6,532 & 1,993 & 20 \\
\hline Other & 1,907 & 1,157 & 39 \\
\hline Total & 11,114 & 4,623 & 100 \\
\hline
\end{tabular}

Net production $=$ gross production less costs

Column 4: estimation by the author.

Source: National income 1955, ERA R-10-19-1, 3; estimation based on ERA R-1-5-406, 1. 5-6.

Transition to command economy implied cutting down international trade and the exchange of technological innovation. Less economic integration meant a rise in tendencies of autarchy of single households, enterprises, ministries or regions. The command economy needed a special way of managing enterprises, based on plan fulfilment and not economic efficiency. ${ }^{53}$ Special solutions developed to cope with the situation, but those topics should be discussed in a different paper. After the transition to command economy was finished, Estonia participated in the general development pattern of the Soviet Union. Under Khrushchev and in the early Brezhnev years continuous economic growth and a steady improvement of the standard of living led to the image of the 'Golden Sixties', arguable the best period in Soviet history. In the second half of the 1970s the setting was replaced by 'stagnation', which meant in the economic sphere a slow-down of growth.

\section{Conclusion}

Because of the transition to command, Estonia could not recover from the war even ten years after the end of fighting. The conditions did not allow for rapid real growth. In the opposite, agricultural policy destroyed the potential of growth and reduced output substantially. Consumption was constrained in the name of investment and defence. This caused thousands of additional deaths and a dramatic decline in the standard of living in the 1940s, but led to no positive results. On the long run, the

\footnotetext{
53 On running a Soviet factory see the classical study: Joseph S. Berliner, Factory and Manager in the USSR (Cambridge MA: Harvard University Press, 1957).
} 
country was brought on a less efficient path of development. Transition to command economy was something like the worst possible scenario. Concerning the population, Stalinist command economy in the 1940s had a similar outcome like Nazi exploitation policy during German occupation. Only in the 1950s should the situation substantially improve, first in the towns and in the second half of the decade in the countryside, too. Seen in the perspective of the last century, the transition to command is clearly responsible for Estonia's weaker economic performance in comparison to countries which have been considerably poorer in the 1930s like Spain, Portugal or Greece. The catch-up process of the inter-war period ended and the gap to more developed economies widened thanks to the transition to command economy. Only after regaining independence, Estonia could successfully continue to catch-up after a second, post-socialist transition. ${ }^{54}$ The future will show, when the levels of Estonian GDP and incomes will reach the average of the European Union, but there should be no doubt that without the experience of the command economy the country would have followed at least the example of Southern Europe.

\footnotetext{
54 According to the estimation of Eurostat, Estonian per capita GDP adjusted to purchasing power parities was 41.8 percent of the EU-27 in 1997 and 67.9 percent in 2007.

http:/ / epp.eurostat.ec.europa.eu/ (accessed October 10, 2009).
} 